\title{
The Effect of Endorphin Massage towards Decreasing Low Back Pain In Third Trimester Pregnant Women
}

\author{
$\underline{\text { Ivana Argo Cahyani1); Sri Winarsih }{ }^{1)} ; \text { Arfiana }^{1))}}$ \\ ivana.argo@gmail.com
}

\begin{abstract}
Background: Pregnancy becomes a meaningful experience with all the changes both physically and psychologically. One of the changes is discomfort that occurs in the third trimester is lower back pain. Lower back pain can cause disruption of daily physical activity. Endorphin massage can be one of the measures to reduce pain in third trimester pregnant women because it releases endorphins from light massage and positive affirmations from the husband.

Methods: This research was conducted in the working area of Pare Public Health Center Temanggung District. The methods used Quasi Experimental with Non-Equivalent Control Group Design. The population of this study were all third-trimester pregnant women with a gestational age of $>$ 36 weeks, its about 46 people. The tool used the data collection an observation sheet on the scale of Mankoski pain. Data analysis used Wilcoxon test.

Result: The results of the study used Wilcoxon test items, namely $p$ value of endorphin massage group of 0,000 with a value of $Z 3.787$ and the control group $p$ value of 0.025 with a value of $Z 2.235$. This showed that both groups were equally influential, but the endorphins group had a stronger influence compared to the control group.

Conclusion: Endorphin massage had an effect on reduced lower back pain in the third trimester of pregnant women. Endorphin massage contain mild massage and positive affirmations from husband that stimulated the emergence of endorphin so reduce pain sensation roomates. It was expected that endorphin massage can be applied by pregnant women and husband or families as one method of decreasing low back pain because it helped empower husband / families to improve the welfare of pregnant woman.
\end{abstract}

Keyword : Low back pain; endorphins massage; third trimester pregnant women

1) Midwifery Study Program of Magelang, Health Polytechnic of Semarang, Indonesia

Jl. Perintis Kemerdekaan, Magelang, Indonesia

Background. Pregnancy becomes a meaningful experience in a woman's life. In this experience was not followed by changes occur be it physical, mental, and social (Marmi, 2014). Complaints on any pregnant women may result from physiological changes on a quarterly basis. Inconvenience trimester III include increased frequency of urination, constipation, hemorrhoids, varicose veins, shortness of breath, leg edema, heartburn, cramping calf muscles, insomnia and back pain (Rukiah et al., 2009)

(Rukiah et al., 2009) says that increasing abdominal distention in late pregnancy causes changes the center of gravity back toward the two legs and the outline of the body, causing the typical posture on pregnant women before the end of pregnancy is lordosis. Added by (Hani et al., 2010) (Widatiningsih and Dewi, 2017) lordosis dorsolumbal causing traction or compression of the nerves at the root. There stretching for spinal muscles and ligaments got heavy pressure. Supported also by the presence of estrogen and progesterone hormones that contributed to relaxation and increased mobility of the pubic symphysis, sacrococcygeal joints and sacroiliac, causing discomfort and pain in the lower back area

The incidence of back pain during pregnancy is 25-90\% ( $\mathrm{P}$ et al., 2011). According to (Mafikasari and Kartikasari, 2015) the prevalence of pregnant women who experience lower back pain in various regions of Indonesia reaches $60-80 \%$. The factors which are a potential increase.

Lower back pain can cause a negative impact on quality of life for pregnant women because of the disruption of daily physical activity ( $\mathrm{G}$ et al., 2017). Additionally, back pain in pregnant women is also an impact on reducing maternal sleep quality that can degrade the quality of life of the mother and the fetus (Renityas, Sari and Wibisono, 2017). 
Reinforced by the results of the study (Sousa et al., 2015) that there is a relationship between low back pain with a decrease in the quality of sleep in pregnant women $(p=0.021)$

Although lower back pain is a physiological thing in pregnancy, but pregnant women still needed comfort during pregnancy. There are two ways to reduce back pain, by pharmacological and non-pharmacological methods. Pharmacological methods is using analgesics but taking into account the effect of the drug to the fetus (S et al., 2015) .The use of analgesic drugs routinely or continuously can be risky for the fetus include the risk of respiratory problems in infants, the risk of miscarriage, malformation, the risk of premature closure of the ductus arteriosus, oligohydramnios, neonatal hemorrhage (Dublin, 2018). Nonpharmacological method that is by exercise, cold or warm compresses, massage or massage, or corset belt abdomen or pelvis buffer, acupuncture or acupressure, chiropractic, aromatherapy, yoga (Khanna, Khanna and Gupta, 2016)

The massage that can reduce back pain on pregnant women is endorphin massage. Endorphin massage method is a touch or light massage therapy is quite important given to pregnant women (Kuswandi, 2013). This method can stimulate the body to release endorphins with stimulate to release hormones by massage and positive affirmation of a husband who makes the women feel calm and comfort. Endorphin is a neurotransmitter or neuromodulators endogenous opioids that inhibit the delivery of pain stimuli by sticking gets opiate receptors in the nervous system of the peripheral or central nervous system that can block pain messages that were released in response to pain and increasing inhibition of pain (Chaudry and Gossman, 2019) .

Methods. This type of research was quasy experimental study with nonequivalent control group design. The sampling technique used in this study is total sampling counted 42

Result and Discussion. Before performing endorphin massage, the scale of pain in third trimester pregnant women can be seen in the table below:
Table 1 Distribution of pain scale before Performing endorphin massage

\begin{tabular}{lcccc}
\hline Pain scale & \multicolumn{2}{c}{$\begin{array}{c}\text { Treatment } \\
\text { group }\end{array}$} & \multicolumn{2}{c}{ Control group } \\
& $\mathrm{F}$ & $\%$ & $\mathrm{~F}$ & $\%$ \\
\hline Not Pain & 0 & 0 & 0 & 0 \\
Mild & 4 & 19,1 & 9 & 42,9 \\
Moderate & 15 & 71,4 & 10 & 47,6 \\
Severe & 2 & 9,5 & 2 & 9,5 \\
Total & 21 & 100 & 21 & 100 \\
\hline
\end{tabular}

The table 1 above showed that low back pain in third trimester pregnant women in both the treatment and control groups was similar. The majority of pain scale is in the category of moderate pain that is $71,4 \%$ in treatment group and $47,6 \%$ in control group.

Endorphin massage provides a benefit for decreasing the pain scale in third trimester pregnant women. The result can be seen in the table below:

Table 2 Distribution of pain scale after Performing endorphin massage in treatment group

\begin{tabular}{lcc}
\hline \multicolumn{1}{c}{ Pain scale } & $\mathrm{F}$ & $\%$ \\
\hline Not Pain & 6 & 28,6 \\
Mild & 12 & 57,1 \\
Moderate & 3 & 14,3 \\
Severe & 0 & 0 \\
Total & 21 & 100 \\
\hline
\end{tabular}

The table 2 above showed the percentage change in pain scale experienced by third trimester pregnant women. Before endorphin massage, $71,4 \%$ experienced moderate pain and $9,5 \%$ had severe pain. After endorphin massage, $28,6 \%$ had no pain, $57,1 \%$ had mild pain and $14,3 \%$ had moderate pain. No more patients with severe pain were found.

Data analysis used Wilcoxon Test showed the effect of endorphin massage on low back pain, as shown in the table below.

Table 3 The Effect of Endorphin Massage towards Decreasing Low Back Pain In Third Trimester Pregnant Women used the Wilcoxon test

\begin{tabular}{cccc} 
Change & frequency & $\mathrm{P}$ value & $\mathrm{Z}$ score \\
\hline Decrease & 17 & 0.000 & -3.787 \\
Constant & 4 & & \\
Increase & 0 & & \\
Total & 21 & & \\
\hline
\end{tabular}

Based on the table 3 above, it appears that there is a decrease in the pain level category that is equal to 17 respondents 
and 4 respondents had a constant pain level category.

Wilcoxon statistical test, with the results of the value of $Z=-3.787$, this means that endorphin massage can reduce the level of low back pain in third trimester pregnant women by 3,787 degrees or 3,787 times; $p=$ 0,000 , this shows that there is an effect of endorphin massage on the reduction of low back pain in third trimester pregnant women

This study proves that prior to endorphin massage, the average pain level is in the moderate pain category with characteristic pain that interferes with activity and interferes with concentration. Lower back pain is back pain that occurs in the lumbosacral area which usually will increase in intensity as the gestational age increases because this pain is due to a shift in the center of gravity of the woman and the posture of the pregnant woman (Varney, 2010).

The pain can caused by several factors. Increased weight and structural changes in pregnancy change the dimensions of the body and center of gravity caused the condition of lordosis (increased lumbosacral curvature) accompanied by a compensatory mechanism of the cervical vertebrae area (the head tends to be anteriorly flexed) to maintain balance. Lordosis can be exacerbated by the bending of the shoulders, and large mammals. Lordosis if not corrected will cause tension ligaments and muscle structures that cause discomfort / back pain during pregnancy or afterwards (Widatiningsih and Dewi, 2017) Excessive bending, walking without resting, and lifting weights, especially when the woman was tired can add stretch to the back (Varney, 2010).

There are two ways to deal with back pain, namely the pharmacological and nonpharmacological methods. However, the use of analgesic drugs regularly or continuously can be at risk for the fetus including the risk of respiratory problems in infants, the risk of miscarriage, malformations, the risk of premature ductal arteriosus closure, oligohydramnios, neonatal bleeding (Dublin, 2018). Non pharmacological methods, namely with exercise, cold or warm compresses, abdominal or pelvic support belts or corsets, acupuncture or acupressure, chiropatic, aromatherapy, yoga, and massage (Khanna, Khanna and Gupta, 2016)
One massage that can reduced back pain in pregnant women is the endorphin massage method. Endorphin massage method wass a touch therapy or light massage which is quite important given to pregnant women (Kuswandi, 2013). Endorphin massage can exert a decrease in pain because when done body massage will produce endorphin. Endorphin are produced by the HPA (Hiptalamus Pituitary Adrenal) System. These hormones are neurotransmitters or endogenous opioid neuromodulators that inhibit the delivery of pain stimuli by attaching to the opiate receptors in the peripheral nervous system and the central nervous system so that they can block pain messages that were released in response to pain and increase pain inhibition (Chaudry and Gossman, 2019)

Massage stimulation in the area of pain becomes stimulation of the peripheral nerves (Judha, Sudarti and Fauziah, 2012). This stimulus activated a blocking neural inhibitor system transmission of pain in the spinal cord and other parts of the nervous system. This impulse was transmitted up to the synaptic inhibitor fibers in the dorsal corn so that it stimulates the release of endogenous opiods (endorphins) in reticularis formatio (Mander, 2012).

The presence of pain stimuli from 2 factors (changes in body posture and hormones) irritates or stimulates the appearance of pain impulses from the viseroreceptors. So that the process of transduction through visero receptors. After the transduction process occurs, the next process is the transmission process. Transmission or distribution of pain impulses occurs through the process of synapse. Pain impulses must be converted to electrochemical energy before they can travel from one neuron to the next. Pain signals are transmitted from one part of the nervous system to other nerves along the neuron chain. There was no physical contact between the nervous system but the action potential was transmitted from one neuron to another through chemicals released as electrical activity. This chemical was called neurotransmitter. Visero receptors stimulated neurotransmitters to moved from peripheral nerve fibers to the dendritic receptors side of the brain through the spinal cord. Information from the body is transmitted to the brain through 3 main pain pathways, spinothalamus, spinorecticularis, spinoservicalis. The most important spinal cord 
needle for transmitting pain impulses is the spinothalamic jar. Through the spinothalamic pathway, pain impulses were processed in the presence of ascending and descending neuro interconnections in the dorsal horn. Furthermore dorsalis cornu flows all pain input into the brain and finally the body is accepted as pain (Judha, Sudarti and Fauziah, 2012).

Besides from massage, positive affirmations also have a role in producing endorphins. Positive affirmations or suggestions from husbands convert beta brain waves (conscious mind) into alpha brain waves (unconscious mind) in the cerebral cortex. After that the sensing association process occurs where the stimulus was analyzed, understood and arranged into a real message or impulse in the brain so that the brain recognizes the object and meaning of the message. The mind was the result of "stimulation patterns" will involve the cerebral cortex, thalamus, limbic system and the upper part of the brain stem reticular formation (Guyton and Hall, 2011)

So if the massage and positive affirmation from the husband were combined it can caused pain impulses to the brain to decrease or disappear and eventually there is a decrease in pain

Conclusion and Suggestions. This study proved that endorphin massage has an effect on the decrease in the low back pain scale with the Wilcoxon test results showing a $Z$ score of -3.787 with a $p$ value : 0.000 . Endorphin massage had an effect on reducing lower back pain in the third trimester of pregnant women. Endorphin massage contain mild massage and positive affirmations from husbands that stimulate the emergence of endorphins can reduce pain sensation roomates. It was expected that endorphin massage can be applied by pregnant women and husband or families as one method of decreasing low back pain because it helps empower husband / families to improve the welfare of pregnant woman

Acknowledgements. Thanks to the researchers say to all those who have helped in completing this research.

\section{References}

Chaudry, S. R. and Gossman, W. (2019) 'Biochemistry; Endorphin', StatPearls. Available at:
470306/.

Dublin (2018) 'PRESCRIBING IN PREGNANCY (3): FREQUENTLY ASKED QUESTIONS', National Medicine Information Centre. St James Hospital. Available at: file:///D:/MANR/3. EDISI 3/manr/NMIC Bulletin August 2018 - PRESCRIBING IN PREGNANCY (3)FREQUENTLY QUESTIONS .pdf.

G, I. et al. (2017) 'Back Pain during Pregnancy and Quality of Life of Pregnant Women', Primary Health Care Open Access, 07(01), pp. 1-6. doi: 10.4172/21671079.1000261.

Guyton and Hall (2011) Buku Ajar Fisiologi Kedokteran. Jakarta: EGC.

Hani, U. et al. (2010) Asuhan Kebidanan pada Kehamilan Fisiologis. Jakarta: Salemba Medika.

Judha, M., Sudarti and Fauziah, A. (2012) Teori Pengukuran Nyeri dan Nyeri Persalinan. Yogyakarta: Nuha Medika.

Khanna, V., Khanna, R. and Gupta, P. (2016) 'Low Back Pain in Pregnancy', International Journal of Recent Surgical and Medical Sciences, 2(1), pp. 23-27. doi: 10.5005/jp-journals-10053-0006.

Kuswandi, L. (2013) Hypnobirthing; A Gentle Way to Give Birth. Jakarta: Pustaka Bunda.

Mafikasari, A. and Kartikasari, R. I. (2015) 'Posisi Tidur dengan Kejadian Back Pain (Nyeri Punggung) pada Ibu Hamil Trimester III', Surya, 07(02), pp. 26-34. Available at: https://stikesmuhla.ac.id/wpcontent/uploads/26-34-Ratih-IndahK.pdf.

Mander, R. (2012) Nyeri Persalinan (. Jakarta: Penerbit Buku kedokteran EGC.

Marmi (2014) Asuhan Kebidanan pada Masa Antenatal. Yogyakarta: Pustaka Pelajar. https://www.ncbi.nlm.nih.gov/books/NBK 
P, K. et al. (2011) 'Pregnancy-related low back pain.', Hippokratio, 15(3), pp. 2050-10. doi: 10.16194/j.cnki.311059/g4.2011.07.016

Renityas, N. N., Sari, L. T. and Wibisono, W. (2017) 'EFEKTIFITAS ACUYOGA TERHADAP KELUHAN INSOMNIA PADA IBU HAMIL TRIMESTER III DI MASYARAKAT AGRICULTURE TRADITIONAL DI WILAYAH KERJA PUSKESMAS NGANCAR KABUPATEN KEDIRI', Jurnal Ners dan Kebidanan, 4(2), pp. 98-103. doi: 10.26699/jnk.v4i.

Rukiah, A. Y. et al. (2009) Asuhan Kebidanan I (Kehamilan). Jakarta: Trans Info Media (TIM).
S, S. et al. (2015) 'Pain Management in Pregnancy: Multimodal Approaches', Pain Research and Treatment. doi: doi: 10.1155/2015/987483.

Sousa, V. P. S. de et al. (2015) 'Quality of Sleep in Pregnant Woman with Low Back Pain', Fisioterapia em Movimento, 28(2), pp. 319-326. doi: 10.1590/01035150.028.002.ao12.

Varney, H. (2010) Buku Ajar Asuhan Kebidanan. 4th edn. Jakarta: EGC.

Widatiningsih, S. and Dewi, C. H. T. (2017) Praktik TerbaikAsuhan Kehamilan. Yogyakarta: Trans Media. 